Debt Restructuring and Notions of Fairness

Sarah Paterson*

This article examines concern for fairness in the way in which loss is distributed when a company or financial institution facing financial difficulties is restructured. It shows how this concern is often grounded in loose notions of fairness, or generalisations from one situation to another, rather than in detailed analysis. Adopting an interdisciplinary approach, it builds an analytical frame for the fairness debate in debt restructuring. It shows why rigour is important in identifying fairness concerns, in weighing them against other considerations, and in applying concerns which arise in one scenario to another, and illustrates the types of policy mistake or policy incoherence which can arise if this is not done.

Keywords: Debt Restructuring; Reorganization; Corporate Insolvency; Corporate Bankruptcy; Fairness

We think of fairness as an intuitive concept, confident that as the colloquial expression goes 'we will know it when we see it'. Substantive unfairness is usually associated with some sort of imbalance: between how one person is treated compared with another; between effort put in and reward gained; between what we legitimately expect and what we get; between how losses fall on the weak and upon the strong. Procedural unfairness, too, reflects this sense of an uneven playing field: between the rights which different parties have to participate in a process or between how favoured and unfavoured parties are treated, or between the rights of those in a powerful bargaining position and the rights of everyone else. But not every case of imbalance will be unfair, 
and many factors may vindicate the situation. Closer examination reveals a slippery concept, which eludes a single definition applicable to all contexts and which suffers from various levels of abstraction unless it is applied to a real situation.

Indeed, if we rely on our intuition we face three risks. First, we risk generalising from one situation to another when the situations ought properly to be differentiated from each other. Secondly, to the extent that we suggest reform to address a fairness concern, that reform may be only weakly related to the real fairness issues in the particular context. Finally, when we weigh fairness concerns against other considerations, we may have a poorly defined idea of what it is that we are putting in the balance. This article argues that our repeated failure to identify systematically our fairness concerns in different types of debt restructuring in English law has led us into all three of these traps. Drawing broadly on scholarship from diverse fields such as moral and political philosophy, biological sciences, psychology, organisation theory, group theory and economics, the article seeks to unpack the principles and the procedural demands which are bound up in some measure in our intuitive sense of what is fair, and to apply them in a rigorous way to three different types of debt restructuring: a restructuring of a small or medium sized enterprise (SME); a restructuring of a large corporate; and a restructuring of a financial institution in English law. In each case, a fairly typical scenario is described to ground the analysis, which reveals repeated failure to distinguish one type of restructuring case from another, to identify accurately where the fairness concerns are lurking, and to decide what we are putting in the fairness bucket of the trade-off scales. ${ }^{1}$ In short, it reveals the policy mistakes which may arise if we give 'our

\footnotetext{
*Assistant Professor of Law, LSE. Earlier versions of this paper were presented in the Oxford Law and Finance Lecture Series in February 2016 and at INSOL International's Academic Colloquium in July 2016. The author is grateful to participants at both events for comments. All views expressed are the author's own, and she is responsible for any errors and omissions.
} 
unscrutinised instincts an unconditional final say'. ${ }^{2}$

The analysis concentrates exclusively on fairness. It does not consider the trade-off between fairness and other objectives (such as sustaining the putatively unfair situation because another, fairer outcome would cost more than the benefits it would deliver or would provide the wrong incentives for some of the stakeholders), or utilitarian objections (because a situation which differentiates between classes of stakeholder in its approach to the fairness of the case would make the stakeholders worse off overall), or with arguments that what we might consider to be questions of fairness should properly be reinterpreted as economic questions. In short, its objective is not to argue that fairness per se should prevail over other considerations, but rather to explore, as an initial question, the quality of fairness in each of the situations with which it is concerned. In each case the analysis has been divided between what are termed 'principles of fairness', which are the principles we apply to a given outcome to determine whether the result is fair, and procedural fairness made up of the factors which determine whether the process by which the outcome was arrived at was itself fair. This division proved no easier to handle than the fairness notion itself, and the reader may on occasion take issue with the allocation of principles between procedure and substance, but given the law's commitment to procedure some attempt to identify a line between outcome and procedure seemed essential.

Finally, the extent to which notions of fairness can properly be said to be contingent upon history, geography and culture is controversial, but many scholars would argue that there are significant

1 See also L. Kaplow and S. Shavell, Fairness versus Welfare (Cambridge, Massachusetts and London, England: Harvard University Press, 2006), 79 fn 121 and accompanying text (discussing whether a mode of analysis arguably appropriate in one context should be applied without alteration in another).

${ }^{2}$ A. Sen, The Idea of Justice (London: Penguin Books, 2010), 51. 
and important national value differences as to what is fair. ${ }^{3}$ As this article focuses on English law debt restructuring, an in-depth cross-cultural analysis is not attempted and the literature which is drawn upon focuses principally on England and the US. Further research might usefully consider how the analysis maps onto other debt restructuring regimes, but that is for another day.

\section{SME RESTRUCTURING}

In a typical (controversial) English law debt restructuring of a financially distressed SME, the owner/managers of the company launch an auction process to sell the business and assets as a going concern. They line up a licensed insolvency practitioner (chosen by, or with the agreement of, the bank which finances the company) to act as administrator should the bidding process fail to attract sufficient interest to meet all of the company's debts in full, so that the company needs to be placed in an insolvency process. The owner/managers subscribe for all of the shares in a new company (bidco). Bidco bids in the auction at a price slightly above the amount outstanding to the seller's fully secured bank, but below the amount sufficient to repay all of the company's existing creditors. The auction process attracts only low bids, so that bidco is successful.

Bidco then negotiates a sale and purchase agreement with the seller's administrator-in-waiting, financing the purchase price by borrowing a fully secured loan from the seller's bank. Once the loan agreement has been agreed with the bank and the sale and purchase agreement has been agreed with the seller, the directors of the seller appoint the administrator and place the company

\footnotetext{
${ }^{3}$ See, for example, J. Elster, Local Justice: How Institutions Allocate Scarce Goods and Necessary Burdens (Cambridge: Cambridge University Press, 1992), 149.
} 
into administration. In English law this appointment can be made out-of-court. ${ }^{4}$ The sale and purchase agreement is immediately signed by the administrator and bidco, and the purchase price is paid to the seller. Together with the owner/managers, the bank agrees with the administrator that the seller has five suppliers who should be paid in full for all invoices outstanding at the date of the administration. Many other small suppliers have substantial outstanding debts with the company at the administration date but these debts are not paid in full; apart from payments to the five selected suppliers, certain amounts due to employees and a small deduction which is legally required to be divided amongst all the unsecured creditors, the purchase price is distributed to the bank as the seller's secured creditor. ${ }^{5}$ After the transaction is completed and the economy has begun to recover, bidco raises a new, cheaper loan from alternative lenders and repays the bank in full. The owner/managers continue to own all of the shares in the newly restructured business.

For some time there has been a sense of moral outrage with this pre-packaged administration solution, troubling government and prompting a series of reviews. These reviews have tended to concentrate on the question of whether, in our example, the bid vehicle is purchasing the business and assets at below market price. ${ }^{6}$ Yet, as we shall see, when we examine our intuitive reaction to this pre-packaged restructuring scenario other circumstances of the case implicate notions of fairness.

\footnotetext{
${ }^{4}$ Insolvency Act 1986. Sched B1 para 22

${ }^{5}$ So that, in effect, the bank's existing loan to the seller is replaced by a fully secured loan to bidco, which now owns all of the seller's assets.

${ }^{6}$ See, for example, the recent Graham Review (2014), available at http://www.gov.uk/government/publications/grahamreview-into-pre-pack-administration (last accessed 25 July 2016).
} 
The SME Restructuring and Principles of Fairness

Fairness, when used in the context of the distribution of money or goods, is strongly associated with treating identically situated persons equally or, if there is not enough to go around, at least proportionately, ${ }^{7}$ sometimes referred to as the principle of 'horizontal equity'. ${ }^{8}$ Of course, in a real world situation we need to decide the criteria by which we will determine whether creditors are 'identically situated' or not. In other words, some differences will go to the question of differentiating the party's claim and others will not. ${ }^{9}$ In an institutional setting we typically develop well-defined criteria by which we decide whether or not one party is equal with another. ${ }^{10}$ Sometimes these concepts are codified in rules or laws and sometimes they are simply widely understood.

When a company is in administration, the broadest differentiating criterion in English law is whether a party has security or not. ${ }^{11}$ After that, English law chooses to treat some of the claims of employees before the claims of other creditors, ${ }^{12}$ makes a relatively small proportion of the realisations of certain secured creditors available to unsecured creditors, ${ }^{13}$ and elevates the claims of creditors who dealt with the administrator after appointment above those of creditors who

\footnotetext{
${ }^{7}$ Aristotle The Politics edited and translated by E Baker (New York: Oxford University Press, 1946), Book III Chpt XII
} [1282b].

${ }^{8}$ E.E. Zajac, Political Economy of Fairness (Cambridge, Massachusetts and London, England: The MIT Press, 2001), 120. See also Prudential Assurance Co Ltd v PRG Powerhouse Limited [2007] BCC 500.

${ }^{9}$ N. Rescher, Fairness (New Brunswick, New Jersey and London, England: Transaction Publishers, 2002$), 18$.

${ }^{10}$ Zajac, $\mathrm{n} 8$ above, 106.

${ }^{11}$ To some extent secured creditors stand outside the administration, realising their security and only claiming the balance of their debt after deducting the amount they have realised; see Insolvency Rules 1986, rule 2.83.

${ }^{12}$ Insolvency Act 1986, s 175 and Insolvency Act 1986, Sched B1 para 65(1).

${ }^{13}$ Insolvency Act 1986, s 176A. 
have dealt with her before. ${ }^{14}$ Adopting Walzer's terminology, these rules mark out the principle of equal treatment in English insolvency law, and its boundaries. The first way in which the SME restructuring situation makes us uncomfortable is that, as Walzer puts it, 'something roundabout or even clandestine' seems to be happening which crosses these boundaries. ${ }^{15}$ The owner/ managers and the bank make their determination as to which unsecured creditors to pay in full and, as this deviation from the principle of equal treatment happens in a way which is largely subjective and unobservable, we have a strong sense of unfairness. A number of justifications can be advanced; crucially, that the suppliers who are paid in full are objectively different because they are more critical to the business than the other suppliers and that English insolvency law permits payment in full to so-called 'ransom creditors' in marking out the principle of equal treatment. ${ }^{16}$ Yet no reasons are given to explain why these creditors are critical, and the unpaid trade suppliers have no straightforward right of appeal. ${ }^{17}$ We will return to this issue later when we consider the concern for procedural fairness.

\footnotetext{
${ }^{14}$ Insolvency Act 1986, Sched B1 para 99 and Insolvency Rules 1986, rule 2.67.

${ }^{15}$ M. Wlazer, Spheres of Justice: A Defense of Pluralism and Equality (US: Basic Books, Inc, 1983), 99.

${ }^{16}$ The analysis is moderately complex but relies, amongst other things, on the fact that a party is not prohibited by the moratorium which arises on administration from terminating a contract for the insolvency of its counterparty, potentially giving a critical supplier a 'ransom' position by insisting on full payment as a condition of continued supply (Re Olympia \& York Canary Wharf Ltd [1993] BCC 154), on Insolvency Act 1986, Sched B1 para 66 which permits an administrator to make a payment other than in accordance with the normal rules of distribution where 'he thinks it is likely to assist the achievement of the purpose of the administration', and on Insolvency Act 1986, Sched 1 para 13 which empowers the administrator to make 'any payment which is necessary or incidental to the performance of his functions'.

${ }^{17}$ Note, in particular, the ability of the administrator to make the payment if he 'thinks' it is likely to assist the achievement of the purpose of the administration - essentially a rationality standard (see also fn 56 below and accompanying text).
} 
It may be possible to justify deviation from the principle of equal treatment on the basis that one person is more deserving than another or, on the other hand, to explain our intuitive sense that a situation is unfair by concluding that someone has not got what they deserve. In order to explore either claim it is necessary to somehow rank or order what we count as deserving for the purposes of reward, and this is further complicated by the fact that the 'dueness condition' has both an objective and a subjective quality (getting what one believes to be one's due). ${ }^{18}$ In his examination of our biological instinct for what is fair, Sun describes it as a requirement that rewards should be proportional to the contribution which a participant has made to the overall endeavour. ${ }^{19} \mathrm{He}$ explains that this principle should apply equally in the downside scenario. In other words, those who benefit when things are going well should bear a greater proportional loss when things go badly. ${ }^{20}$ Arneson attributes weight not only to objective considerations, but also to how hard an individual has tried, given the particular circumstances in which she finds herself and her particular condition. ${ }^{21}$ This idea of prioritising deservingness based on effort also has a long history, familiar in the depression-era concept of the 'deserving poor' who struggled with poor background conditions but with maximum determination and commitment when compared with the 'idle rich'. It stands in contrast to modern, competitive individualistic doctrine, in which inequalities can be justified 'because they are perceived to be rewards for unequal achievement, talent, rationality

\footnotetext{
${ }^{18}$ P. Woodruff, The Ajax Dilemma: Justice, Fairness and Rewards (New York: Oxford University Press, 2011), 143; B.H. Sheppard, R.J. Lewicki and J.W. Minton, Organizational Justice: The Search for Fairness in the Workplace (New York: Lexington Books, 1992), 21-24.

${ }^{19}$ L. Sun, The Fairness Instinct: The Robin Hood Mentality and Our Biological Nature (New York: Prometheus Books, 2013), 62. See also E.A. Lind and T.R. Tyler, The Social Psychology of Procedural Justice (New York: Plenum Press, 1988), 10 .

${ }^{20}$ Sun $n 19$ above, 63.

${ }^{21}$ R.J.Arneson, 'Desert and Equality' in N Holtug and K Lippert-Rasmussen (eds) Egalitarianism: New Essays on the Nature and Value of Equality (Oxford: Clarendon Press, 2007).
} 
and merit'. ${ }^{22}$

Whilst the bank may be convinced of the merit-based fairness of the case, there is long run evidence in social history of a tendency for wider society to be unimpressed by the 'mere' contribution of finance. David Kynaston's four volume history of the City of London provides a rich treasure trove of examples, ${ }^{23}$ and the debate over the social usefulness of much of what the finance industry does has been reignited with passion and vigour after the financial crisis by, amongst many others, Thomas Pikkety, John Kay and Atif Mian and Amir Sufi. ${ }^{24}$ Banking in the UK has been a virtual oligopoly for almost two centuries and there is a sense (heightened after the financial crisis) that the banking community wields significant political power, influencing the making of insolvency laws which serve to protect its interests and producing outcomes which are unfair. $^{25}$ In our example, the stranded trade supplier has contributed not just money but also commercial effort to the endeavour, but appears to have been inadequately rewarded, whilst the bank's position is entirely protected and the owner/managers retain their equity. Related research in the field of group psychology provides further insight. This research suggests that we tend to deny the deservingness of groups to which we do not belong, whilst valuing too highly the rights of

\footnotetext{
${ }^{22}$ R.S. Taylor, Reconstructing Rawls: The Kantian Foundations of Justice as Fairness (Pennsylvania: The Pennsylvania State University Press, 2011), 254. See also S. Asma, Against Fairness (Chicago: The Chicago University Press, 2013), 10.

${ }^{23}$ D. Kynaston, The City of London Volumes 1-IV (London: Pimlico, 1995-2001).

${ }^{24}$ T. Pikkety, Capital in the Twenty First Century (Cambridge, Massachusetts and London, England: The Belknap Press of Harvard University Press, 2014); J. Kay, Other People's Money: Masters of the Universe or Servants of the People (London: Profile Books, 2015); A. Mian and A. Sufi, House of Debt: How They (and You) Caused the Great Recession, and How We Can Stop It Happening Again (Chicago: The University of Chicago Press, 2015).

${ }^{25}$ Walzer $n 15$ above, 121.
} 
our own group. ${ }^{26}$ As the distribution to the fully-paid trade creditors relies on the discretionary assessment of the owner/managers, the bank and 'their' administrator, social psychology would suggest that a narrative of 'us' and 'them' could rapidly be constructed, and that the trade supplier will develop an in-group identity with all the other unpaid trade suppliers, and contrast it with the outcome for the other groups. ${ }^{27}$

One plausible response to these concerns in the context of a market exchange is that the trade suppliers negotiated their supply contracts in the shadow of English restructuring law, and thus consented to the position in which they now find themselves. Many scholars have identified the idea of consent as legitimising market exchange, so that questions of fairness do not arise, or at least not explicitly. ${ }^{28}$ In Robert Nozick's work, a market exchange is always voluntary, notwithstanding practical considerations which effectively limit choice, provided those exercising rights which result in the practical constraints do so legitimately. Thus, the fact that a small supplier is forced to transact as a practical matter on terms which he may not have chosen if he had occupied a stronger bargaining position is not sufficient to render his decision-making involuntary. ${ }^{29}$ Consent is also strongly linked to the broader concept of responsibility: a party should be held responsible for choices freely made (see, for example, the examination of the

\footnotetext{
${ }^{26}$ M.H. Sherif, O.J. Harvey, B.J. White, W.R. Hood and C.W. Sherif, The Robbers Cave Experiment: Intergroup Conflict and Cooperation (Connecticut: Wesleyan University Press, 1988), 10, 18, 19.

${ }^{27}$ M. Bond, The Power of Others: Peer Pressure, Group Think and How the People Around Us Shape Everything We Do (London: Oneworld Publications, 2014), 3.

${ }^{28}$ R. Nozick, Anarchy, State and Utopia (New York, Basic Books, Inc,1974); D. Gauthier, Morals by Agreement (Oxford: Clarendon Press,1986), Chapter IV.

${ }^{29}$ Nozick n 28 above, 262. See also an excellent discussion of this point in M Allingham, Distributive Justice (London and New York: Routledge, 2014), 76-78.
} 
subject by Fleurbaey), ${ }^{30}$ or even for Dworkin's complex idea of 'option luck' (accepting an isolated risk such as bankruptcy of a counter party which an individual should have anticipated and might have declined) as distinct from 'brute luck' (situations which were not in any sense a deliberate gamble). ${ }^{31}$

Yet in the real world of the SME none of these concepts of consent, responsibility or luck takes us as far as it might. We are all aware that under certain conditions, 'the free market is not all that free $^{\prime 32}$ and of the superior bargaining position and expertise which the bank had in negotiating a fully secured loan agreement, compared with the position of the weaker trade creditor in the market. We suspect that, even if she had wanted to, the small trade creditor could not have adjusted the price of the contract to reflect fully her risk on default nor, in many cases, have insured against it, and we are familiar with the idea that conditions agreed in the market may be suspect as a result of inequality of bargaining power. ${ }^{33}$ Nozick's work is admirable as a dazzling intellectual exercise but nonetheless struggles as a theory which we can relate to our own experience of the real world. We assume that the bank had a team of professional advisers to assist it in reaching the best possible deal, and inside knowledge of the situation as it unfolded. In other words, we are dubious about the quality of consent, responsibility or bargained for bad luck. As Sandel puts it, 'Consent matters, even if it is not all there is to justice. But it is less decisive than we sometimes think'. ${ }^{34}$ Ultimately, the unpaid, unsecured trade creditor is suspected of lacking any market power to ensure that the risks which she takes are connected to her actual effort and

\footnotetext{
${ }^{30}$ M. Fleurbaey, Fairness, Responsibility and Welfare (Oxford: Oxford University Press, 2008).

${ }^{31}$ R. Dworkin, Sovereign Virtue: The Theory and Practice of Equality (Cambridge, Massachusetts: Harvard University Press, 2000), 73 .

${ }^{32}$ M.J. Sandel, Justice: What's the Right Thing to Do? (London and New York: Penguin Books, 2010 ), 81.

${ }^{33}$ B. Barry, Justice as Impartiality (Oxford: Clarendon Press, 1996), 51.

${ }^{34}$ Sandel n 32 above, 144.
} 
initiative. $^{35}$

Linked to, but somewhat different from, the concept of 'just deserts' (and consent) is the idea of legitimate expectation. In other words, when the parties engage in a venture according to defined rules they expect all others who have submitted to the same rules to deliver their side of the bargain. ${ }^{36}$ Thus, in dealing with the counter party, the unsecured trade creditor expects her contract to be observed to the fullest extent of the counter party's ability, and feels a sense of outrage when she concludes that the counter party has not done so. ${ }^{37}$ Of course, we might argue that the contract was concluded in the shadow of restructuring law, so that the weak trade supplier consented to the outcome. We have dealt with that point above, and the arguments made there are not repeated here. Instead, the point is made that the stranded trade supplier may object to the SME situation on the basis that her legitimate expectation that she would be paid in full or, if not in full, to the maximum extent that the company is able to afford, has not been met whilst the equivalent expectations of the bank and the family have been met. In other words, there is a discrepancy between the outcomes which we think ought to prevail and those which have. $^{38}$

The mirror of 'just desert' and legitimate expectation for the wronged party is a desire to see those who are responsible for loss suffer for the harm which they have inflicted, what Mark Warren calls a 'pathological form of fairness'..$^{39}$ Sun has shown how hidden elements of our reasoning process

\footnotetext{
${ }^{35}$ Walzer $n 15$ above, 118.

${ }^{36}$ Barry n 33 above, 33.

${ }^{37}$ Zajac n 8 above, 106.

${ }^{38}$ Sun $n 19$ above, 132.

${ }^{39}$ ME Warren, 'Democracy and the Everyday Origins of Fairness' in JP Sarra (ed) An Exploration of Fairness: Interdisciplinary Inquiries in Law, Science and the Humanities (Canada: Carswell, 2013).
} 
lead us to the ignoble emotion of spite. ${ }^{40}$ Fleurbaey carefully analyses what he calls the 'sour grapes' effect and demonstrates that, whilst a consequentialist analysis (with which this article is not concerned) might militate against a fresh start for those who have caused the harm, there should not be 'a principled opposition to it'. ${ }^{41}$ Nonetheless, as Sandel puts it 'outrage is the special kind of anger you feel when you believe that people are getting things they don't deserve'. ${ }^{42}$ In the SME situation, the owner/managers who have brought about the trade creditor's ruin retain all of the equity in the business. The stranded trade creditor may simply want to make them pay.

This brings us to our last, important principle of fairness in the distribution of money or goods: that loss should not fall on those least able to bear it. In John Rawls's search for a theory of the ideally fair institutions of a sovereign state, the lot of the worst off in society assumes central importance in the so-called difference principle - the idea that inequalities can be admitted where, and to the extent that, they improve the lot of those worst off in society. ${ }^{43}$ Work in the biological sciences has shown how powerful our compassion for the weak is. ${ }^{44}$ What is implicated here is a sense of 'vertical equity', ${ }^{45}$ comparing the position between classes of stakeholder rather than simply the position within a class. It also finds expression in the responsibility debate, 'What must be done ... is to determine who in each circumstance class (i.e., a subpopulation of individuals with identical circumstances) is worst-off, compare them across classes, and give priority to the worst-off among

\footnotetext{
${ }^{40}$ Sun n 19 above, 138.

${ }^{41}$ Fleurbaey n 30 above, 181-182.

${ }^{42}$ Sandel n 32 above, 7.

${ }^{43}$ J. Rawls, Justice as Fairness: A Restatement E. Kelly (ed) (Cambridge, Massachusetts and London, England: The Belknap Press of Harvard University Press, 2001), 42-43. See also T. Pogge, John Rawls: His Life and Theory of Justice (Oxford: Oxford University Press, Eng tr, 2007), 106-115.

${ }^{44}$ Sun n 19 above, 27.

${ }^{45}$ Zajac n 8 above, 120.
} 
them ${ }^{46}$ In the SME case, the weakest trade creditors bear the brunt of the loss.

The SME Restructuring and Procedural fairness

When we think about fairness we think not only about fairness of outcome, but also the fairness of the procedure by which the outcome is reached. Indeed, some scholars would argue that provided the procedure is accepted, the result can never be impugned. ${ }^{47}$ This leaves open the possibility that a party who does not like the result claims not to accept the procedure, so that what may matter is not whether everyone has agreed to the procedure, but rather whether they would agree to it if they were behaving reasonably. ${ }^{48}$ For the moment the point is made that the procedure may be fair if a stakeholder acting reasonably would accept it, even if a stakeholder acting unreasonably in the real world rejects it.

For many scholars an important aspect of procedural fairness is the number of voices which are heard. ${ }^{49}$ This may be drawn very widely (because, although the relevant actor is disinterested in the particular situation, her voice may have an important and interesting perspective), or may be limited to anyone whose interests are involved. ${ }^{50}$ Research in the fields of social psychology and organisation theory suggest that the ability for someone affected by the procedure to be heard within it impacts their view of how fairly they have been treated, even if there is no or very limited capacity to influence decision making. ${ }^{51}$ Moreover, a so-called voice system provides feedback to

\footnotetext{
${ }^{46}$ Fleurbaey n 30 above, 83.

${ }^{47}$ Barry n 33 above, 150.

${ }^{48}$ Woodruff n 18 above, 111.

${ }^{49}$ Lind and Tyler n 19 above, 5, 9, 49-51, 59, 170-172, 176-177.

${ }^{50}$ Sen $n 2$ above, 44.

${ }^{51}$ Sheppard, Lewicki and Minton n 18 above, 140-141.
} 
those running the procedure. Thus plurality of voice is an important requirement for bankruptcy scholars who subscribe to the 'forum' view of insolvency; the widest number of perspectives on the situation ought to be offered so that no opportunity is overlooked which might otherwise be aired. ${ }^{52}$ This directly impacts on the third reason for voice within the insolvency procedure, in that it provides the opportunity to correct a course of action which has been settled on, or to make changes going forward.

Whatever view one takes of 'voice', and of procedural fairness, in the SME case a limited number of stakeholders has the chance actively to participate: the owner/managers, the bank, and an administrator chosen by them (with whom we might assume the bank has a pre-existing relationship). An administrator is required to hold a meeting of creditors to discuss her proposals for the administration, but not where the company is so insolvent that no return to unsecured creditors is anticipated (other than a legislatively fixed small return). ${ }^{53}$ Moreover, case law has established that, even where English insolvency law does require a meeting to be held, when an administration sale is 'pre-packaged' the administrator is not required to hold the meeting before the sale is completed, ${ }^{54}$ so that creditors are effectively presented with a fait accompli. Challenging the administrator's decision to pursue the sale transaction rather than, for example, a different debt restructuring transaction is also fraught with difficulty, so that the unpaid suppliers lack an effective right to appeal. Crucially the administrator is entitled to move to a sale transaction if she 'thinks' it would achieve a better result for creditors as a whole, ${ }^{55}$ (essentially a

\footnotetext{
${ }^{52}$ V Finch, Corporate Insolvency Law: Perspectives and Principles (Cambridge: Cambridge University Press, $2^{\text {nd }}$ ed, 2009), 43-44 (reviewing the literature).

${ }^{53}$ Insolvency Act 1986, s 176A.

${ }^{54}$ Re T\&D Industries plc (in administration) [2000], WLR 646; Re Transbus International Ltd [2004] 1 WLR 2654 interpreting Insolvency Act 1986, Sched B1 para 68.

${ }^{55}$ Insolvency Act 1986, Sched B1 para 3(1)(b).
} 
rationality standard), ${ }^{56}$ and the courts are extremely reluctant to interfere in the administrator's commercial decision making. ${ }^{57}$ Indeed, recent cases have shown just how difficult it is to unwind a certain pre-packaged administration sale in order to pursue a different, uncertain debt restructuring. ${ }^{58}$

Of course, building 'voice' into the system also gives rise to consequentialist concerns, particularly the question of whether the cost of doing so outweighs the benefit. Indeed, the Small Business, Enterprise and Employment Act 2015 will abolish a number of creditor meetings within the insolvency process, apparently as a result of this concern. ${ }^{59}$ Yet work in organisation theory suggests a number of ways in which voice can be built into a procedure efficiently. ${ }^{60}$ This work in organisation theory does, though, give us pause for thought on another issue. It identifies that a significant reason for adopting a voice system is 'fundamentally to preserve and protect the power of those who currently govern the organisation' ${ }^{61}$ This leads directly to our next concern: eliminating bias and partiality from the system.

Adam Smith employed the idea of the 'impartial spectator' in his ethical scheme to examine our conduct, and to consider whether that conduct can objectively be regarded as fair. ${ }^{62}$ This idea of a lack of bias, or of impartiality, links both to the question of whether any unequal treatment can be

\footnotetext{
${ }^{56}$ H.C. Standing Committee col 5699 May 2002.

${ }^{57}$ Four Private Investment Funds v Lomas [2009] BCLC 161.

${ }^{58}$ Case Management Conference In the Matter of Coniston Hotel [2014] EWHC 397; Hockin and others $v$ Matsden and another [2014] Bus L.R. 441; Holgate and another v Reid and another [2013] EWHC 4630 (Ch).

${ }^{59}$ Small Business, Enterprise and Employment Act 2015, s 122.

${ }^{60}$ Sheppard, Lewicki and Minton n 18 above, 148-155.

${ }^{61}$ Ibid 154.

${ }^{62}$ A. Smith, Theory of Moral Sentiments (London: T. Cadell, extended version 1790; republished Oxford 1976), III, i, 2.
} 
supported, and the quality of the procedure by which the unequal outcome is arrived at. ${ }^{63}$ Thus John Rawls, in his search for how the fairness ideal should be embedded within political institutions, employed the thought experiment of a hypothetical agreement by members of society in the original position behind a thick veil of ignorance. In other words, Rawls strives for an objective or impartial assessment of the fairness condition by stripping his imagined actors of any knowledge of the attributes which they will have, and the conditions which they will be in, in a real world setting. ${ }^{64}$

Once we consider the demand to avoid bias as a 'foundational idea' of fairness, ${ }^{65}$ the SME case makes us still more uneasy. First, the choices between which suppliers to pay and which to leave unpaid are reached by parties who are clearly insiders, and who have strong, vested interests to influence their decision making. Moreover, the appointment of the administrator out of court means that judges who are screened for, and subjected to rules to remove, concerns of bias so that they can preside over disputes where questions of fairness of outcome and of process might arise are not involved in the decision making. ${ }^{66}$ The administrator has been selected and paid for by the owner/managers and the bank. The administrator is a repeat player, and likely to be influenced by the bank's wishes, ${ }^{67}$ so that she is not in fact the disinterested gatekeeper which we might like her to be. This problem with identifying a truly neutral gatekeeper is a familiar one: it has been identified in the work of Enriques and Macey on independent valuers in share transactions, ${ }^{68}$ in

\footnotetext{
${ }^{63}$ Rescher n 9 above, 23; C. L. Carr, On Fairness (Aldershot: Ashgate, 2000), 16; Sen n 2 above, 54.

${ }^{64}$ J. Rawls, A Theory of Justice (Cambridge, Massachusetts: Harvard University Press, 1971), 17.

${ }^{65}$ Sen $n 2$ above, 54.

${ }^{66}$ Sun $n 19$ above, 83.

${ }^{67}$ S. Paterson, Bargaining in Financial Restructuring: Market Norms, Legal Rights and Regulatory Standards’ (2014) 14(2) The Journal of Corporate Law Studies 333, 359-360.

${ }^{68}$ L. Enriques and J.R. Macey, 'Creditors Versus Capital Formation: the Case Against the European Capital Rules'
} 
work on ombudsmen in organisation theory, ${ }^{69}$ in post financial crisis literature on the role of the rating agencies, ${ }^{70}$ and explicitly in the literature on administration. ${ }^{71}$ It is an explicit policy objective of the US Chapter 11 process to eliminate bias by providing a central role for the court, whilst the court has a minimal role in an English administration. Once again efficiency concerns outside the scope of this article come into play, but once again our examination of the metafairness of the case helps us to identify the issues with which we are concerned. Ultimately, we suspect that the decision which was reached did not put questions of power aside, and thus did not arrive at an impartial decision.

The idea of protection against abuse of power is also fundamental to our sense of fairness. Often, when we refer to an unfair outcome or process we mean that one of the participants has exploited their position of power so as to be able to bend the rules of the game to their own advantage, and in a way which is inappropriate to the nature of the activity which they are participating in. ${ }^{72}$ Thus Rawls's thick veil of ignorance strips the parties of the ability to gain bargaining advantage over one another. ${ }^{73}$ This leads to difficult questions about delineating the point at which it ceases to be

(2001) 86 Cornell Law Review 1165, 1167.

${ }^{69}$ Sheppard, Lewicki and Minton n 18 above, 155.

${ }^{70}$ B. Eichengreen, Hall of Mirrors: The Great Depression, the Great Recession and the Uses - and Misuses - of History (Oxford: Oxford University Press, 2015), 79.

${ }^{71}$ Finch n 52 above, 435; J Armour and RJ Mokal, 'Reforming the Governance of Corporate Rescue: The Enterprise Act 2002' (2003) 1 Lloyds Maritime and Commercial Law Quarterly 28, 36-37; V. Finch, 'Insolvency Practitioners: The Avenues of Accountability' (2012) 8 Journal of Business Law, 645; R Stevens, 'Security After the Enterprise Act' in J Getzler and J Payne (eds) Company Charges: Spectrum and Beyond (Oxford: Oxford University Press, 2006), 160. ${ }^{72}$ Carr n 63 above, 9.

${ }^{73}$ Taylor $\mathrm{n} 22$ above, 34 as he puts it, 'by situating OP parties symmetrically with respect to one another, it [the veil of ignorance] assures that the terms of cooperation that arise will be fair ones, reflecting norms of reciprocity instead of replicating preexisting inequalities'. 
morally legitimate to use bargaining strength to improve one's position. ${ }^{74}$ But the ideal is that the system should control abuses in such a way that no-one in a position of power is able to gain an advantage which she does not deserve merely through the exercise of that power. The SME situation gives us cause for concern that the vulnerable trade creditors have not been protected from the power of the bank, part of the financial elite, by the appointment of an administrator chosen by them. Moreover, the family are clearly powerful insiders in the case and have better information which they are able to exploit in reaching their desired outcome.

In sum, whilst other considerations may make the SME scenario the best policy solution, it nonetheless triggers many concerns which are bundled in different combinations in our own concept of what is fair. Importantly, these concerns go beyond the policy focus on the price at which the sale transaction is completed. It is tempting to hold that the analysis is the same in any corporate restructuring where some creditors are excluded, but as we shall see the analysis needs to be revisited where only financial creditors are implicated, or where we are concerned with the special situation of a financial institution. Fairness considerations in debt restructuring are not generisable because they are intrinsically related to the circumstances of the case.

\section{LARGE CORPORATE RESTRUCTURING}

Many private equity sponsors finance acquisitions of large corporates through a small amount of equity and significant amounts of debt (so that the loans are known as 'leveraged loans'). ${ }^{75}$ The

\footnotetext{
${ }^{74}$ See J.E. Roemer, Theories of Distributive Justice (Cambridge, Massachusetts and London, England: Harvard University Press, 1998), 91-92.

${ }^{75}$ For an explanation of why the private equity industry favours this model, see L. Gullifer and J. Payne, Principles of Corporate Finance (Oxford and Portland, Oregon, Hart Publishing, 2015), 776.
} 
debt is often divided into a senior secured loan, and a loan or loans which are also secured but which rank behind (or junior) to the senior loan in insolvency (and which consequently attract higher pricing).

Of course, one of the consequences of carrying a significant amount of debt is that the company has a relatively high interest bill to pay. Furthermore, before the financial crisis, most European leveraged loan agreements contained financial covenants which tested, on an ongoing basis or periodically, whether the borrower's financial health was being maintained (for example, by testing that the ratio of financial indebtedness to earnings remained within prescribed levels). ${ }^{76}$ If these financial covenant ratios were breached, the lenders became entitled to accelerate the loan and demand that it was immediately repaid, so that if the loan could not be refinanced the company would become insolvent. Many private equity transactions faced debt service or financial covenant compliance problems during the financial crisis, and the market value of the companies at the time was often significantly less than their debt. In these circumstances, one common approach was to seek to swap some or all of the company's senior loans into equity but (after five to ten per cent of the equity had been reserved for management to incentivise them) to offer nothing or only a very small amount for the junior lenders. If there was disagreement about the debt-for-equity swap amongst the senior lenders it was common to take advantage of England's scheme of arrangement procedure which enabled the transaction to be imposed on the senior lenders with a lower threshold than the unanimous consent mandated in the loan agreement. If the junior lenders sought to challenge the transaction (or threatened to do so), the scheme of arrangement could be 'twinned' with a pre-packaged administration pursuant to which the company's business and assets were sold to a new vehicle owned by the converting lenders in return for a release of their debt (which usually exceeded the current market price for the business

\footnotetext{
${ }^{76}$ A. McKnight, The Law of International Finance (Oxford: Oxford University Press, 2008), 149-151.
} 
and assets), leaving the junior creditors stranded in the 'old' company which had been stripped bare. During the restructuring negotiations, it was common for the debt to trade widely, so that the creditors who eventually entered into the restructuring had often acquired their interest at a discount. In the years after the worst of the crisis, in an improved macroeconomic environment, it was often possible to sell or list the shares in the newly restructured company for a substantial profit.

The Large Corporate Restructuring and Principles of Fairness

English law clearly marks the boundaries of the principle of equal treatment in a scheme of arrangement first, by requiring a determination as to whether creditors can vote as a single class, or should be divided into separate classes for voting purposes, ${ }^{77}$ and secondly, by mandating that the scheme can only proceed if creditors in each separate class accounting for a majority in number and 75 per cent in value of the claims present and voting in that class vote in favour of the scheme. ${ }^{78}$ A body of case law has developed which indicates that the crucial question for the purposes of determining who is to be placed in each class is the rights which the members of the class have before, and the rights which they will receive in, the scheme, ${ }^{79}$ so that in the large corporate scenario it is likely that the senior lenders will vote as a single class. At first sight, therefore, no particular concern for 'horizontal equity' arises.

However, matters are not quite so straightforward. It is possible, for example, that some of the senior lenders voting on the scheme have entered into lock-up agreements in which they commit to support the scheme before it is proposed, have received consent fees in return for voting in

\footnotetext{
${ }^{77}$ Practice statement [2002] I WLR 1345.

${ }^{78}$ Companies Act 2006, s 899(1).

${ }^{79}$ See, for example, Re Hawk Insurance Co Ltd [2001] 2 BCLC 480 at [23].
} 
support of the scheme, hold an interest in another part of the company's capital structure which may influence their overall assessment of the restructuring or are content to support the scheme only because of the discount at which they acquired their interest. As a result, after voting on the scheme, a second court hearing is held at which the court decides whether to sanction the scheme. At sanction the court will be alert to the possibility that '... any group of creditors even in properly constituted classes have been unfairly coerced by the majority within their class in terms of having been corralled by people whose rights appear similar but whose objectives and interests were poles apart' ${ }^{80}$

Furthermore, if the junior creditors are not offered anything, and the scheme is to be twinned with a pre-packaged administration sale in order to strand them in an empty shell company, the junior creditors will have no vote in the scheme because, strictly, they are not being asked to vote on a change in their rights. In other words, the company is entitled to leave them out of the scheme of arrangement. ${ }^{81}$ However, a party who is left outside the scheme can appear at the sanction hearing to argue that the scheme is unfair because the class of creditor of which she is a member should properly have been offered something within it. The English court will address this question by determining whether the creditors who have been left out of the scheme retain an economic interest in the company so that they should have been offered some consideration in it. ${ }^{82}$ In determining whether the creditors have such an economic interest, the English court puts particular weight on the position the creditors would be in if the scheme of arrangement were not sanctioned. Where the company is financially distressed, this typically leads to an inquiry into whether the price which an administrator would receive in a market sale of the business and

\footnotetext{
${ }^{80}$ Primacom Holding GmbH v A Group of the Senior Lenders \& Credit Agricole [2013] BCC 201 at [57].

${ }^{81}$ Sea Assets Limited v Perusahaan Perseroan (Persero) PT Perusahaan Penerbangan Garuda Indonesia [2001] EWCA Civ 1696.
}

${ }^{82}$ MyTravel [2004] EWCA Civ 1734; Re Bluebrook Ltd 2 BCLC 123. 
assets at the time of the restructuring would be sufficient to make a distribution to the creditors excluded from the scheme. However, asset prices may be generally depressed if there has been a slowdown in the business or finance cycle. ${ }^{83}$ This means that even though the current market price may indicate that the excluded creditors have no economic interest in the company, if the other creditors receive all of the equity in the company in exchange for their debt in the scheme of arrangement they may make a significant profit when asset prices recover.

To address this concern, US bankruptcy law adopts a valuation standard based on professional valuation opinions, rather than current market price established through an auction process. ${ }^{84}$ Thus it does not decide who should receive an equity allocation in the debt restructuring based on the current price in the market, but rather adopts traditional valuation techniques such as discounted cash flow, comparable transaction and private equity valuations in an attempt to give more credit for the prospect of a post-restructuring recovery in the price of the business and assets than a purchaser in the distressed market at the time of the sale might be willing to give. The very existence of this alternative is significant, because research into how we perceive unfairness has shown that it is in part determined by our ability to think about alternatives. ${ }^{85}$ It has given rise to lively debate amongst judges, scholars and practitioners as to whether senior creditors in an English restructuring receive 'too good a deal', ${ }^{86}$ and whether England should move

\footnotetext{
${ }^{83}$ D. Adler, The New Economics of Liquidity and Financial Frictions (CFA Institute Research Foundation, 2014).

${ }^{84}$ See Paterson n 67 above, 348-356 and S. Paterson, 'Rethinking Corporate Bankruptcy Theory in the Twenty-First Century’ (2015) OJLS available at http://ojls.oxfordjournals.org/cgi/content/full/gqv038?ijkey=ESvFGKwAj61TLDz\&keytype=ref.

${ }^{85}$ R Folger, 'Reformulating the Preconditions of Resentment: A Referent Cognition Model' In: JC Masters and WP Smith (eds) Social Comparison, Social Justice and Relative Deprivation: Theoretical Empirical and Policy Perspectives (Hillsdale, New Jersey: Erlbaum,1987) 183-215 cited in Sheppard, Lewicki and Minton n 18 above, 50. ${ }^{86}$ Re Bluebrook Ltd $\mathrm{n} 82$ above at [49].
} 
towards the US approach. ${ }^{87}$

In addressing the fairness aspect of this question, and leaving aside the broader advantages and disadvantages of the US approach, ${ }^{88}$ we must remember the socio-historical context in which the valuation approach in Chapter 11 was adopted. It is tempting to see it as what Sen has called a 'transcendental framework', ${ }^{89}$ in other words an objective standard of what is fair in a debt restructuring formulated and developed by the brilliant academics who designed Chapter 11 independently of the action and behaviour in bankruptcy which they saw at the time. If this were the case, then the normative distributional concerns of Chapter 11 would remain constant over time. However, it is suggested that there is considerable 'historical conditioning' in the theory, ${ }^{90}$ and that it was very much a product of what the academics saw of the actual operation of debt restructuring. In particular, in the 1970s when Chapter 11 was developed, it was usual to compromise trade creditors in a large, corporate debt restructuring as well as in an SME restructuring. In other words, there would have been fewer contextual differences between the SME restructuring and a large corporate restructuring. Thus we must be very cautious about how we apply 'inherited ideas and concepts' ${ }^{91}$ to the new situation with which we are faced, conscious

\footnotetext{
${ }^{87}$ M. Crystal and R. Mokal, 'The Valuation of Distressed Companies: A Conceptual Framework Part 1' (2006) International Corporate Rescue 63; N Segal, 'Schemes of Arrangement and Junior Creditors - Does the US Approach to Valuations Provide the Answer?' (2007) 20 Insolvency Intelligence 49; AFME and Weil, Potential Economic Gains from Reforming Insolvency Law in Europe February 2016, 17-18 available at www.afme.eu (last accessed 25 July 2016).

${ }^{88}$ For discussion of these broader advantages and disadvantages see Paterson $\mathrm{n} 67$ above.

${ }^{89}$ Sen $\mathrm{n} 2$ above, 15-18.

${ }^{90}$ This term is borrowed from Maurice Dobbs, see M Dobb Theories of Value and Distribution Since Adam Smith (Cambridge: Cambridge University Press, 1973), 16.

${ }^{91}$ Ibid 17.
} 
that 'ideas have a genealogy of their own'. ${ }^{92}$

We should, therefore, pause to ask ourselves what we mean by 'too good a deal' in this scenario. We do not mean that the quality of what the parties has contributed, or the effort they have dedicated to supporting the endeavour, is somehow different. Each has contributed money, and it is likely that none of them played a particularly active role in monitoring the financial health of the company, or acting as a 'whistle blower', as might once have been the case. ${ }^{93}$ Crucially, the junior debt will have attracted higher pricing than the senior debt to reflect its increased riskiness on default, recalling Sun's requirement that the quality of receiving what one deserves applies in the downside as well as the upside. ${ }^{94}$ We might argue, therefore, that provided the legal consequences were known in advance, in this scenario concepts of 'deservedness' are of considerably reduced significance. We might also despatch the requirement for satisfaction of 'legitimate expectations' in the same way.

The principle of free exchange in which the junior creditors consented to, are responsible for and took calculated chances on the situation in which they now find themselves is also more compelling in this scenario than in the SME scenario. These are financial creditors who have the full gamut of investment opportunities available to them. They are likely to be properly advised, and to understand the risks which they are taking. We do not have the same sense of a sophisticated insider of the financial elite pitched against a rookie. To the extent that the financial creditor represents a pension fund seeking the high risk, high return investment necessary to meet

\footnotetext{
${ }^{92}$ Ibid

${ }^{93}$ For the role of banks as monitor and whistle blower in the days of so-called relationship banking see J. Armour and S. Frisby, 'Rethinking Receivership’ (2001) 21 OJLS 73-102.

${ }^{94}$ Sun $\mathrm{n} 19$ above and accompanying text.
} 
the requirements of an ageing population, we might argue that the pension fund has no more choice in investment selection than the weaker trade creditor, and no better ability to adjust price in competitive market conditions. We might be sceptical about the ability of investment managers accurately to predict and price for risk of and return on default, so that a US approach to valuation becomes crucial to protect pension investments for wider society, or conversely we might be confident that investors can predict and price risk and return on default, so that we fear the traditional English approach has an impact on the availability of credit. Or we might fear that unless we move to a system more recognisable to US creditors, they will not be willing to undertake the necessary learning process to feel happy to invest in businesses in the UK at a time when we are keen to attract direct foreign investment. ${ }^{95}$ These are vast issues and for another day. For the moment, the point is made once again that the argument is not that current corporate restructuring practice meets the paradigmatic trade-off between fairness and other considerations. Rather it is that the extent to which the situation falls short of our notions of fairness is not as extreme as it is in the SME case where a classic battle is fought between the weak and the strong. In the same way, whilst the argument that loss should not fall on those least able to bear it resonated in the context of weak trade creditors ranked against powerful financial creditors, it has less salience when we are considering financial creditor pitched against financial creditor.

One of the criticisms of financial markets after the financial crisis is the apparent absence of cultural or ethical norms to control bad behaviour. ${ }^{96}$ This is most commonly ascribed to

\footnotetext{
${ }^{95}$ On this point see, in particular, S. Franken, 'Comparative Insolvency Law: A Comparative Institutional Analysis' (2014) 34 OJLS 97.

${ }^{96}$ D. Awry, W. Blair and D. Kershaw, 'Between Law and Markets: Is there a Role for Culture and Ethics in Financial Regulation' (2013) 38 Delaware Journal of Corporate Law, 191.
} 
globalisation and diversification of the market: it is well documented that cultural norms are seeded and thrive best in relatively homogenous groups. ${ }^{97}$ Yet this belies a fundamental shift in ideas. Modern markets do not look to the era of gentlemanly codes of conduct with misty-eyed nostalgia. ${ }^{98}$ There is a well-documented dark-side to homogenous groups with strong codes of behaviour: the codes which develop to keep members in the group may equally well be used to keep others out. ${ }^{99}$ Indeed, well-known work in the 1950s lamented the complacent and sluggish state of American capitalism and the apparent stifling of entrepreneurialism. ${ }^{100}$ In contrast, Pikkety has described the 'meritocratic extremism' of modern markets, ${ }^{101}$ and modern finance markets are more likely to judge a situation solely by an economic calculus. Of course, this raises issues too extensive to investigate here. But one benefit of a market bonded by an economic calculus is its 'hyper-rationality', in other words, its reluctance to allow emotional responses, such as spite, to play any role in determining the economically rational response. Thus it is arguably less likely that there will be a sense of a need for retributive justice when the creditors who have suffered the harm are sophisticated economic actors.

The Large Corporate Restructuring and Procedural Fairness

\footnotetext{
${ }^{97}$ See, for example, F Fukyama, Trust: the Social Virtues and the Creation of Prosperity (London and New York: Penguin Books, 1995), 277.

${ }^{98}$ For this period see, for example, D. Kynaston, The City of London: A Club No More 1945-2000 (London: Pimlico, 2002); P. Augar The Death of Gentlemanly Capitalism (London and New York: Penguin Books, 2001).

${ }^{99}$ Fukyama n 97 above, 314.

${ }^{100}$ See, for example, D. Riesman The Lonely Crowd (New Haven and London: Yale University Press, 1961) and W.H. Whyte The Organisation Man (Pennsylvania: University of Pennsylvania Press, 2002).

${ }^{101}$ T. Pikkety n 24 above, 334.
} 
We may still have some concerns for procedural fairness because it is likely that the administrator is appointed by management together with the senior creditors, and we may remain concerned that the 'voice' of the junior creditors is not adequately heard. Moreover, although in our example the pre-packaged administration is 'twinned' with a scheme of arrangement providing a forum for objections, in another case where the senior creditors are ad idem the pre-packaged administration may be used alone to strand the junior financial creditors much as it was used in the SME case to strand trade creditors. However, it is still likely that the junior lenders are sophisticated financial creditors who are aware how a transaction of this type is likely to play out. They have the financial wherewithal to employ professional advisers to put their legal and economic arguments, and are unlikely to be wholly excluded from the process, or to be surprised by it. ${ }^{102}$ Whereas it will have been a key part of the strategy of the SME case to keep the transaction from as many trade creditors as possible, precisely to ensure that they continued to deal with the company in the shadow of the pre-packaged administration, no such concerns arise in speaking to the junior creditors. This is because it is likely that the junior creditors will be prohibited by the terms of the inter-creditor agreement from taking action against the company in the negotiation period. ${ }^{103}$ These creditors do not require a formal voice system in order to access decision makers - they are perfectly capable of doing so themselves.

Moreover, whilst the investment bank's valuation (and any marketing process which supports it) is crucial to the outcome, and we may have concerns about the independence of management in producing the business plan on which the valuation will depend (particularly given the equity

\footnotetext{
${ }^{102}$ For this argument in the case law see Re Bluebrook Ltd n 82 above at [63].

${ }^{103}$ C. Howard and B. Hedger, Restructuring Law and Practice (London: Butterworths LexisNexis, 2014) 56 para 2.106 ; 347 para 6.212 ; and $354-356$ para 6.237.
} 
which they stand to gain in the transaction ranking behind a much reduced debt burden), ${ }^{104}$ the quality of the bias problem is arguably different from the SME situation. First, as noted above there is significantly less selection between equally situated creditors. Secondly, although the administrator in this scenario is likely to have been retained by those leading the transaction, she is also likely to have worked in other situations in which creditors who are currently in the junior debt held the fulcrum securities. ${ }^{105}$ In other words, whereas in the SME transaction she is likely to have overriding loyalty for the single player whose patronage is crucial for future appointments, ${ }^{106}$ her long-run loyalties are less clear in this situation. We may have concerns that the situation is not as free from bias as we might ideally like, but it stands at a shorter distance from that position than the SME case. We have thus already trailed, and can dispatch relatively quickly, discussion of protection against abuse of power. In the large corporate restructuring scenario we have painted we are dealing with the 'high hats' of the financial elite. ${ }^{107}$ We have already examined the reduced patronage concerns in the appointment of the administrator. We have also touched on the advisory team available to the junior creditor, and their implicit understanding of the situation.

In sum, the argument is not that the large corporate debt restructuring represents the paradigmatic marriage of fairness and efficiency. There may be other, fairer outcomes which are supportable or good arguments (outside the scope of this article) for preferring another solution on the basis that it will, for example, improve ex ante investment incentives which will encourage

\footnotetext{
${ }^{104}$ For a detailed discussion of this point and possible solutions to it see S. Paterson, 'The Paradox of Alignment: Agency Problems and Debt Restructuring' forthcoming European Business Organisation Review.

${ }^{105}$ The fulcrum securities are those which are likely to receive some consideration in the restructuring, but not to be repaid in full, which often provides their holders with effective control of the case.

${ }^{106}$ See fn 71 above and accompanying text.

${ }^{107}$ The term 'high hats' is borrowed from D.M. Kennedy, Freedom from Fear: The American People in Depression and War 1929-1945 (New York and Oxford: Oxford University Press, 1999), 237.
} 
the raising of capital, or create better incentives ex post for the directors, or protect pension funds for wider society. Instead, the point is made that the large corporate situation is not as far away from what we might regard as the ideally fair solution as that of the SME restructuring. In other words, we need to adjust how we think about fairness in the new circumstances of the case. As we shall see, this need critically to assess our mode of thinking about notions of fairness comes into stark relief in the context of financial institutions.

\section{FINANCIAL INSTITUTION RESTRUCTURING}

Before the crisis many US financial institutions had issued bonds backed by residential mortgage loans to low income families in the United States (so-called sub-prime mortgages). Often the purchase of these residential mortgages had been funded through the short term money markets, and the mortgages were subsequently packaged together (or securitised) to support highly rated bonds. This proved a very attractive line of business, but eventually the funding market, and the market which traded in the securities, began to doubt the quality of the mortgages in the portfolios. Funding liquidity in the money market and the interbank market abruptly dried up. This meant that European financial institutions which had relied heavily on these markets for funding were no longer able to access them. At the same time, many of these institutions had also invested heavily in the US sub-prime securitisations, so that the asset side of their balance sheets took a heavy hit. During the financial crisis, European governments dealt with this by using taxpayers' money to recapitalise the banks' balance sheets and to provide them with funding liquidity; in other words, the banks were bailed out. After the financial crisis the 'bail-in' tool has been developed, enabling the authorities forcibly to convert certain liabilities of distressed financial institutions into equity, recapitalising the relevant institution's balance sheet and rebuilding confidence in it. Insofar as the fairness analysis is concerned, many of the same 
considerations apply to bail-in as in the large corporate debt-for-equity swap scenario. But there are certain crucial distinctions introduced into the fairness analysis by the fact that the entity to be restructured is a regulated financial institution.

The Financial Institution Restructuring and Principles of Fairness

In the era before the Great Depression bank runs were a common feature of the US business cycle. Often it was not clear what sparked the loss of confidence in an institution, but once the psychological fear gripped depositors, the bank could fail with frightening speed. Depositors rushed to withdraw their cash, and the bank, in a desperate attempt to stave off financial collapse, began to liquidate assets at fire-sale prices. ${ }^{108}$ It was all too easy for the situation to spread to other financial institutions. In the Depression era it became clear that mechanisms were needed to improve depositor confidence. This led to a number of reforms, including the introduction of deposit insurance, ${ }^{109}$ and legislation to ring fence deposit taking business from other business so that depositors could have confidence that their deposits were not being used to fund other, risky activities. ${ }^{110}$ After these steps were implemented the rate and volume of bank failures slowed dramatically in the US, and US and UK finance markets entered an extended period of relative stability which came to be known as the Great Moderation. ${ }^{111}$

Deposit insurance, however, creates a risk of 'moral hazard': bank executives inured against the risk of having insufficient assets to meet deposit obligations (because the deposit insurer is

\footnotetext{
${ }^{108}$ Ibid $65-67$

${ }^{109}$ A. Admati and M. Hellwig, The Bankers' New Clothes (Princeton and Oxford: Princeton University Press, 2013 ), 31.

${ }^{110}$ Eichengreen n 70 above, 66.

${ }^{111}$ Ibid 3.
} 
standing by to meet the liability, should it arise) take ever riskier action. ${ }^{112}$ At the same time, before the crisis deposit insurance was capped at a relatively low level in the UK so that it did not provide much comfort to modern depositors, and it did not cover (and so did not reassure) the money and interbank funding markets. ${ }^{113}$ Ring fencing of operations never arrived in the UK and was lifted in the US in 1999. ${ }^{114}$ The structure of the finance market changed, with increasingly complex financial arrangements of the type described above (the effects of which were not entirely understood), ${ }^{115}$ and a growth in the so-called shadow banking system outside the regulated sector. ${ }^{116}$ Assumptions that the post-Depression era reforms, sound central bank policy and a better understanding of the business cycle meant there would never again be a bust in the financial system proved to be groundless. Nonetheless, the financial crisis revealed an economic imperative to rescue financial institutions because of a fear that collapse would threaten the fabric of the financial system of the country. Scholars studying the Great Depression had criticised the response of the US Federal Reserve (the central bank) and Government, holding them partly responsible for the depth of the crisis in the 1930 s by, amongst other things, failing to respond with rapid injections of sufficient liquidity for the struggling financial sector. ${ }^{117}$ Many of the policy actors in the financial crisis had studied the response to the Depression and had learnt these lessons. ${ }^{118}$ As a result, the UK Government stepped in, using taxpayers' money to restore banks' balance sheets, and in doing so revealed that before the crisis banks had been able to raise debt

\footnotetext{
${ }^{112}$ R.M. Lastra, Legal Foundations of International Monetary Stability (Oxford: Oxford University Press, 2006), 115.

${ }^{113}$ Eichengreen n 70 above, 172, 180.

${ }^{114}$ Admati and Hellwig n 109 above, 46; Eichengreen n 70 above, 11, 70, 99.

${ }^{115}$ Eichengreen $n 70$ above, 73-75.

${ }^{116}$ Ibid 72 .

${ }^{117}$ Ibid $115,119$.

${ }^{118}$ Ibid 378.
} 
very cheaply because lenders had anticipated precisely this result. ${ }^{119}$ In the post-mortem this has been seen as intolerable to public opinion, and the political imperative that it should never be allowed to happen again is at the heart of the post-crisis legal and regulatory response.

A significant development has been the incorporation of the so-called bail-in tool in the Bank Recovery and Resolution Directive (henceforth the BRRD), ${ }^{120}$ implemented in the UK through amendments to the Banking Act 2009. The bail-in tool effectively enables the regulator to compel holders of certain debt instruments issued by the bank to swap them for equity. This will immediately reduce pressure on the bank's balance sheet and, it is hoped, restore confidence in it. It is also designed to remove the implicit government subsidy for banks by making it more realistic for regulators to restructure a distressed financial institution rather than bailing it out. As a result, bail-in risk should henceforth be priced into the cost of bank debt. However, in order to adjust the price of lending to reflect bail-in risk, a creditor needs reasonable transparency as to how the bailin will occur. To this end, the European Banking Authority has issued a series of regulatory mandates, designed to ensure a reasonably uniform approach between member states on the treatment of capital in bail-in. At the time of writing the regulatory mandates remain in draft form, but the relevant ones for the purposes of allocating consideration (and, therefore, losses) in a restructuring are the Draft Guidelines on the Rate of Conversion of Debt to Equity in Bail-in, Draft Guidelines on Treatment of Liabilities in Bail-in, Draft Guidelines on Treatment of Shareholders First in Bail-in and Draft Technical Standards on Valuation in Bail-in. ${ }^{121}$ Of course, the long-run relevance of the BRRD, and the regulatory mandates which will accompany it, remains in some doubt in the

\footnotetext{
${ }^{119}$ Admati and Hellwig n 109 above, 89; CM Reinhart and KS Rogoff This Time is Different: Eight Centuries of Financial Folly (Princeton and Oxford: Princeton University Press, 2011), 145.

${ }^{120}$ 2014/59/EU, Articles 43 and 44.

${ }^{121}$ Available at http://www.eba.europa.eu/ .
} 
UK since the vote of the people of the UK to leave the European Union in the EU referendum on 23 June 2016. Nonetheless, analysis of the EU position will be relevant whatever approach is ultimately taken in the ensuing EU negotiations.

To this end, the draft guidelines reveal a somewhat Byzantine structure for the valuation exercise. One valuation is carried out by an independent valuer in order to determine the rate of conversion of the debt and allocation of equity amongst debt holders. This is done by valuing the bank as a going concern after it has been successfully restructured, broadly similar to the use of valuation opinions for large corporate restructurings in US bankruptcy described above. A second valuation is carried out (both before and after bail-in) to determine the treatment which creditors would have received if the financial institution had been placed into an insolvency proceeding rather than being restructured using the bail-in tool. As in the traditional English approach in a large corporate restructuring, this valuation is likely to be done using current prices for the bank's assets if they were sold in the market at the time of the restructuring. If a creditor is able to show that she is in a worse position after bail-in than she would have been in if the financial institution had been placed in an insolvency process and its assets realised and the proceeds distributed, she may bring a claim under the 'no creditor worse off' principle enshrined in the BRRD. ${ }^{122}$ But this may be challenging if the bank is facing distress at a low point in the finance cycle when there may be a general lack of funding for banks in the market, so that many banks may be trying to sell assets at the same time to raise funds and there will be few buyers. As more banks seek to sell assets, prices become increasingly depressed, further weakening banks' balance sheets and thus requiring more asset sales to raise funds. This may mean that prices for the bank's assets are particularly depressed at the time of the bail-in. ${ }^{123}$ It would therefore seem to be more promising for a

\footnotetext{
${ }^{122}$ Article 73.

${ }^{123}$ Adler $n 83$ above, 16-17.
} 
creditor to argue for a greater allocation of equity in the bail-in based on the post-restructuring value of the bank. However, it is not at all clear what a creditor can do if she disagrees with the going concern assessment for the purposes of the second valuation, as the only explicit right of appeal in the BRRD is the no creditor worse off principle based on the insolvency valuation.

To the extent that the valuation standards are intended to enable the market to reach a firm view on the position on default, both in deciding to lend and in pricing the lending decision, so that the treatment of the capital in bail-in is legitimised by consent, responsibility and luck, we might have expected clearer standards and clearer rights. This would also address the now familiar charge that creditors have not received what is due to them because, once again, it is suggested that provided the operation of the valuation standards is clear no principled fairness concern arises in the context of bail-in of sophisticated market actors investing in complex debt. ${ }^{124}$ To the extent that we are concerned with 'deservedness' we may simply limit ourselves to clear and transparent rules. As before, this should ensure that the legitimate expectations of powerful market actors are met.

This analysis is reinforced in the unique situation of financial institution restructuring when we consider the fairness principle that loss should not fall on those least able to bear it. Whilst this was not a tremendously meaningful concept when we considered allocation of losses amongst financial creditors in the large corporate scenario, in the context of a financial institution, it is an explicit policy objective that losses should not fall on the taxpayer. Thus, as explained at the

\footnotetext{
${ }^{124}$ As before, we may conclude that other considerations (such as the need to encourage investment in the regulatory capital of financial institutions or to protect investment made by professional investment managers of pension funds for wider society) militate against a more brutal allocation of value. But if this were the motivation, we would expect to see clearer rights accompanying the post-restructuring going concern standard.
} 
beginning, much of the post crisis response has been about ensuring that the system can absorb failure without implicating taxpayers' money. There are many aspects to this, but in the context of bail-in of bank capital it is a clear plank of the valuation standards. It is also explicable in the limited legal right to complain based on the 'no creditor worse off' principle. Yet the role of the going concern valuation is not clear, and whilst it seems unlikely that it will positively impact ex ante lending behaviour (because of its very uncertain role and the lack of clearly enforceable rights which relate to it) it does seem to open up the possibility of litigation ex post with all of the attendant costs for the taxpayer. The question then arises as to whether concern for procedural fairness motivated the complex valuation structure.

The Financial Institution Restructuring and Procedural fairness

The financial institution bail-in solution can be imposed on the creditors in a UK financial institution by the Bank of England. ${ }^{125}$ Thus concerns about procedural fairness in this case may reflect concerns about controlling regulatory behaviour, particularly the exorbitant exercise of regulatory discretion. ${ }^{126}$ Put shortly the concern emerges that regulators who have been provided with extensive regulatory tools will have an overwhelming desire to exercise them, and a new vein of literature relating to regulatory accountability is implicated. However, it is important that we identify this as the new concern in assessing the fairness of the procedure because, whilst the control of regulators has some parallels with the control of market actors explored in the other two situations, it also raises different issues around public interest. It also leads directly to a concern with protection against abuse of regulatory power.

\footnotetext{
${ }^{125}$ Banking Act 2009, s 122A.

${ }^{126}$ Kaplow and Shavell n 1 above, 406.
} 
This concern appears to manifest itself in the BRRD with the extension of valuation to going concern value as well as liquidation value. However, given that the only clear legal right is that provided by the no creditor worse off principle, we might ask to what extent that ambition is met. If we are genuinely concerned with abuse of regulatory power, we might wish to provide stronger enforcement rights for creditors who feel that they should have received a greater allocation on a post bail-in going concern basis. An alternative possibility is that the real benefit of the going concern valuation step comes from making the regulatory process seem, rather than be, fair. ${ }^{127}$ As discussed in the SME situation, work in the field of organisation theory suggests that acceptance of a system may be reinforced by an aura of fairness, even if the changes to the system do not render it fairer in any substantive sense, and notwithstanding that the effect of such a system is to reinforce the acceptance, and therefore the power, of those in control of it rather than to level the playing field. It may be, therefore, that the going concern valuation exists to provide what we might call surface fairness rather than a deep convergence towards a fairness standard. Or it may be that it has arisen from the debate around valuation standards in large corporate debt restructuring and that that is why the overall system lacks clear policy coherence. In other words, it is not clear to what extent the policy prescription has arisen from a clear analysis of the metafairness of the case.

\section{CONCLUSION}

Ultimately, there seems to be a lack of clear thinking about the normative concerns for fairness in the reform efforts around connected party SME pre-packaged administrations, the current debate around valuation standards in large corporate debt restructuring and the evolving valuation

\footnotetext{
${ }^{127}$ For this distinction between 'seeming' and 'being' see Jonathan Glover's distinction between seeming and being moral in his work Humanity: A Moral History of the Twentieth Century (London: Pimlico, 2001), 20.
} 
standards for the BRRD. Each scenario examined neatly illustrates the point which we started with. Not only do we always need to be mindful of other considerations which ought to prevail over our notions of fairness when determining policy responses in restructuring, we must also be clear what the normative concerns for fairness are which we are weighing in the balance. In other words, we must be mindful not simply to rely on intuitions or instincts but rather must critically examine the elements of our loose notions of fairness. Most importantly of all, we should be especially careful not simply to translate notions of fairness from one circumstance to another, without assessing whether some adjustment is required.

Thus it is that, in the context of SME debt restructuring, one of our dominant normative concerns should be the extent to which debt restructuring procedures can address substantive and procedural unfairness which arises between creditors, perhaps by reducing the ability of insiders to protect themselves in the shadow of insolvency law or reducing the right of some creditors to claim a ransom position. We will, of course, have to weigh these normative concerns for fairness against other normative concerns (such as the availability and cost of capital for healthy SMEs), but classic concerns for distributional and procedural fairness are likely to be a significant part of our analysis. However, when we consider large corporate debt restructurings implicating only financial creditors we are less likely to be concerned with unfairness between market participants, and more concerned with how our policy choices affect the market for credit for healthy companies (by negatively impacting the availability of finance or the cost of finance) or our ability to invest for a rapidly ageing population (because much of the money at stake is invested by pension and insurance funds on behalf of us all in search of the necessary yield). When we come to financial institutions, different considerations apply again. We are concerned with unfairness but this time between the market and the taxpayer and (perhaps) between the market and the regulator rather than with unfairness between the market participants. So fairness matters, but the fairness 
question has a different quality. Thus when we weigh our normative concerns for fairness against the consequences of our choices for the ability of financial institutions to raise adequate capital at an appropriate (but affordable) price, quite different fairness concerns go into the scales.

At the time of writing, the Insolvency Service is consulting on reform of the corporate insolvency framework in England and Wales, the European Commission has published a draft directive on substantive minimum standards in preventative restructuring frameworks in the EU and work continues on finalising the regulatory mandates for valuation in financial institution restructuring. These are certainly busy times. Yet it is vitally important that in our haste we also take time to identify what type of debt restructuring is targeted in each of these reform efforts, and that in each case we carefully and specifically locate our fairness (and other) normative concerns within it. If we do this, we will find that a single reform initiative cannot arrive at the right balance for all cases. In other words, policy missteps are inevitable unless we cease generalising our normative fairness concerns in debt restructuring, and take seriously the exercise of considering them in the factual context within which they arise. 